\title{
Programming the Vicious Circle: Austen, Deleuze and Viral Repetition
}

\author{
Mark Horvath and Adam Lovasz \\ Eötvös Lóránd University, Budapest
}

Abstract: Viruses have taken command of cybernetic space. Today, in the age of uploaded exteriorized memory, sociability as such has become a function of algorithmic disincarnation. This fractality, we assert, is a fundamental and primordial condition, an aspect of dynamic (re)integration, a process of negative entropy whose temporality is of unhuman dimensions. One cannot really escape from viral repetition. In the example of the "Austen-virus," textualities return, reappropriated by malware and other malignant agents. The exteriorization of memory perpetuates this repetition, Eternal(ized) Return, what Pierre Klossowski termed "the vicious circle." Eternalization, the rendering and reintegration of memory, correlates with externalization. This circle, this space of disappearance, is haunted by the return of that which refuses to disappear. It is precisely because disappearance is never total that digital temporality and digital memory are haunted by traumatic multiplicities. Through the analysis of concrete examples of Internet hauntologies, we seek to illuminate the many and variegated aspects of haunted digital archivality. As Lev Manovich has written, the Internet as such is characterized by copresence and hybridity. Copresences make possible a kind of blending, a deep remixing that "messes up" conventions and categorizations. Digital hauntology, we argue, is fraught with ambiguity and transgressivity. Agents of multiplicity, such as glitches, bugs and viruses, breed new layers of meaninglessness, spreading chaos throughout networks, blending various strands of code, injecting ruination into coherence. It is our view that the vicious circle as an ontological concept can be of use in helping us come to terms with the many subversive forms of repetition that may be found among the interstices of networks. Through an innovative conceptualization of what we term the "Austen virus, we hope to shed new light on the ontology of Internet media.

In July 2015, Cisco Inc. released its "Midyear Security Report," detailing the latest Internet threats, malwares and viruses. Within the report, we find particularly surprising detail. Among the various strategies used by "adversaries" is the incorporation of textual selections from Jane Austen's Sens $\epsilon$ and Sensibility. As the report highlights, "adding passages of classic text to an exploit landing page is a more effective obfuscation technique than $t$ traditional approach of using random text." Through the exploitation of classical textualities, viral hyperoperativity can hide its productivity and embs itself in networks. "Threat actors," these malignant, spectral entities, are "evolving their schemes to avoid detection." [1] Subterfuge is an eminently textual praxis, a method of avoidance that yields space for overproduction. Local structures, once rendered susceptible to subversion, become weakened and vulnerable to viral replication, which is made manifest through textual recombination and metafictional regeneration. In the case of vi subterfuge, revision lends itself to usage as camouflage. George P. Landow defines hypertextuality as a new decentered form of power, emanating from "a transient, de-centereable virtual center - one created (...) only by one's act of reading." ${ }^{[2]}$ With hypertext, what we have is "a double revaluation," the dissolution of textual hierarchies in which "any attached text gains an importance it might not have had before." [3] Jane Austen, wh subordinated to viral operativity, gains new importance as the peripheral tool of a decentered centrality that tyrannizes local and global network structures with its fearsome dissemination. In the moment when the adversary utilizes Austen's textuality, making of it a tool-being, replication is ma manifest. Programming is invariably disseminative in nature, penetrating through various cocoons and protective atmospheres, generating what Ton D. Sampson has called "the viral atmosphere." $[4]$ The viral atmosphere "marks the point at which... human susceptibility becomes assimilated in the desiring machine." "[5] Virality is a chaotic dispersal of desire, the deterritorialization of textuality. Within the viral atmosphere, textuality becomes hypertextual. But can hypertext ever truly "belong"? Does viral programming have a "place," so to speak? Can there be a place for that which is illegal, unruly, unintegrable?

It is not only computer viruses that have appropriated Austen's literary corpus. Arguably one of the most famous instances of adaptation would be Seth Graheme-Smith's 2009 parody, Pride \& Prejudice \& Zombies, as well as Burr Steers' 2016 horror-comedy film adaptation of the novel. In a cert sense, the hypertextual is also paratextual, in that both terms represent a liminal "in between," a language that "marks a zone of transition between text and non-text." [6] Similarly, once transferred onto a zombie horror narrative, Austen's textuality becomes zombified and viral, spreading rapidly among a preteen and teenage audience. Through the mere addition of a living-dead status, the Austen corpus attains a second life, as evinced by th wave of online fan fiction that followed the film. Paratext generates a premediated, threatening atmosphere, an ethereal realm that creates the preconditions for newer productivities. Persistence is a law that generates emergence, a supersensible thing that overcomes anti-viral resistance, a power that penetrates dense connections while undoing the identity of writing. Adaptation means that originality can proliferate through copying its $\epsilon$ the simulacrum becomes the source of production. Emergence is intensive, a subterranean force that operates underneath existents. Manuel DeLar differentiates intensities from "external differences," defining intensities as forces that "drive fluxes of matter or energy."[7] Virality would be the intensive emergence of paratextual dissemination, a recombinant intensity that pathogenically manifests decognitive processes of infectious repetition. This power is a force that comes into collision with dense connections, enveloped by security apparatuses and firewalls. Contagion and infectious emergence must be maintained if the process of proliferation and dissemination is to continue. Sampson's example of a business disseminating products is eminently applicable to virality in general: "to maintain the virality of the atmosphere... the business enterprise requires the mostly unconscious mutuality or emotional investment of the infected consumer to guarantee that the affective contagion is passed on." ${ }^{[8]}$ Zombie adaptations suited to a preteen audience allow for the application of communication to a younger demographic. Mutuality must be unconscious if infection is to be truly successful. 
It is notable that no human agent is required for the contagion to be repeated, for, in the case of what we may call the "Jane Austen Virus," two machinic sensibilities meet with one another within the halfway realm of paratextuality; as the Cisco report mentions, it is the antivirus program that performs the act of categorization and not the user as such. ${ }^{[9]}$ Pathogenic elements make their advent through indeterminate usages of classic textuality. This development, this subversive tactic, allows pathogens to undermine dense connectivity, undoing communication through an overwhelming, almost infinite productivity. Once it enters into dialogue with the anti-virus program, the virus, enclothed with Austen's majestically classical textuality, seeks through duplicitous means to overcome the resistance of the targeted system. Duplicity and resistance are not exclusively human prerogatives, but characteristic of all objects. Failure and brokenness are engendered by separation from place. Rendered separate from her place in literature, Austen becomes a viral agent precisely because her text appears in the wrong place at the wrong time. She has nothing to do wit the zombie subgenre, yet there is no inherent obstacle to the success of a zombified Austenian literature. One could even argue that she is a loose intensity, a rogue being, a ghost of sorts that contributes to the dissemination of infectious languages. But can Austen's language not be considerec viral, broken and incoherent from the very beginning, even prior to her appropriation by malicious agents? Austen's textuality and Austen, the viral mother, can both be considered as broken objects, for God knows what is breeding within their interiorities. Austen is the mother who gives birth to viral infection. Her womb is a tear in ontological contexture.

An aspect of virality and social contagion emphasized by both Sampson and Gabriel Tarde is the virtuality of concreteness and "obsessive engagement." [10] In order to ensnare consumers within its interstices, the enterprise must engage them through their emotions and desires. Seemin! impossible cultural constructs come about. Even adaptations of adaptations are fully capable of riveting audiences and grabbing the attention of consumers. In spite of fairly negative reviews, Steers' film was a box office success and has contributed to renewed interest in Austenian literature. The world of virality is one that is "made of virtuality, affective flows" and "incorporeal passionate relations." [11] The viral atmosphere not only seduc but also "suggests," demanding full, limitless engagement, even while remaining hidden among the shadows. ${ }^{[12]}$ Interestingly, Sampson identifies a biopolitical aspect to viral atmosphericity: "in what we might call a trend toward the virality of network capitalism, there is certainly a distinct rampin! up of the repetitious spread of affective contagion." [13] Dreadfully, pathogens are just as capable of networking as we are. Viral deployment, accordil to Sampson's epidemological discourse, increasingly deploys the predicative structure of what we shall term, following Pierre Klossowski, "the vicio circle." [14] Discognition, as engendered by the viral, invariably results in the ever more apparent equation of information with what Wendy Hui Kyong Chun has called "ghostly abstraction."[15] The affected element, the haunted entity would be "a ghostly jelly," a substrate that receives the alterity of the virus into its flesh. ${ }^{[16]}$

This penetration by paratextual alterity takes the form of mute repetition, a ghostly abstraction whose durability resides in its collisionality. The Vicio Circle presents itself in the mode of the repetitional, preying upon vulnerable networks through such immaterial avenues as impulses. Imperatives to indeed generate viral atmospheres of nonrepresentation, for how else could Jane Austen become a "security threat"? Aesthetic hybridity seems to $k$ an important characteristic of new media. Pride \& Prejudice \& Zombies is a prime example, being a communication situated within a social setting saturated by gender and cultural anxieties. Various cultural forms coalesce in a chaotic space marked by transgressions of genre boundaries. The breakdown of cultural barriers affords new opportunities for the proliferation and even retroactive projection of zombies into the past. We see twentieth-century media monsters introduced into a completely nineteenth-century Austenian setting. "Information," Chun reminds us, "is 'undead": neither alive nor dead, neither quite present nor absent." [17] We have no knowledge of how Austen became zombified, how her textuality became a tool-being subordinated to virality, but a fair guess would be that digitalization had a role to play in this "accident." Graham Allen differentiates between the "thematic," that which refers to the subject-matter of writing, and the "rhematic," which refers to "the manner in which the text perform its intentions." [18] But do we even need to connect any given textuality with intentionality? Pure thought immediately drops into an ocean of various intensities, ceaselessly colliding with one another, producing sedimentary distributions. Objects are as much inaccessible singularities as they are surfaces for one another. Difference is a productive function, as DeLanda notes: intensive or internal differences, such as a temperature or pressure gradient within one and the same body, are... positive or productive."[19] The virus produces through utilizing, in a paratextual manner, Austen's writi albeit this utilization remains internal, in that every intensity is also an internality. What the virus performs, in the case of its instrumentalization of Austen, is a linkage. Similarly, Steers' film performs a functional merging of two artistic planes.

Connectivity is also productive, as exemplified by the hypertextual forces released into the world in the aftermath of textual linkage: "the linked text, the annotation, exists as the other text, and it leads to a conception (and experience) of text as Other."[20] Landow's remark relating to the "conception" of textual alterity is especially pertinent in relation to viruses and social contagion. The act of infection is also a miraculous conception an act of transfertilization. In material and immaterial systems alike, the proliferation of difference can result in "phase transitions," radically changins the extensive properties of the various network nodes. ${ }^{[21]}$ Without difference, there can be no productivity. DeLanda points out that "a biological population where genetic differences have been eliminated is as unproductive as a thermodynamic system where differences in temperature or pressure have been cancelled through equilibration."[22] Change is predicated upon difference, the re-creation of repetitious activity. The Austen-virı in a self-replicating manner, constantly creates new differences, new hybrid genres. Following upon Steers' film, new ideas work themselves out through the spontaneity of fan bases around the world. Within the lower depths of objects, be they material or immaterial entities, we find centers of cross-communicating intensities, generative differences of intensity that allow change to spread through network typologies. Brokenness only intervenes when causal chains are broken, rendered inoperative. Stasis is inoperativity. Self-creation and self-fertilization contribute to the emancipation of energy.

We seek to outline the contours of an eminently Deleuzian "double science," one that is capable of conceptualizing the black box-like nature of virus and viral entities. When the virus is unveiled, it operates in the manner of an opened box, a Pandora's Box full of illness and chaos. It is here that we must emphasize the heterogeneity of viral overproduction. Interfaces are always already "daemonic," in the sense that "a daemon... is already a medium, an intermediate value albeit one that is not often seen."[23] Once opened, the black box renders all surrounding entities vulnerable to haunting and infection. Alexander Galloway, in a 2010 lecture, differentiates between two types of black box, the "black box cypher" and the "black box function." ${ }^{[24]}$ From complete lack of access, such as that opacity which characterized black box cyphers, the black box has evolved into a 
technologically complex system, "a function defined exclusively through its inputs and outputs."[25] Black boxes are essentially functions, because "they are nothing but a means of relating input to output, they articulate only their exterior grammar, and black box their innards."[26] As perfect a definition of malware as could be formulated!

Difference can only produce if and when it black boxes its innards. Contagion is a series of metamorphoses that only constitute convergence in the last instance, after all network nodes have fallen prey to infection. Network participation is a heterogeneous thread guiding dead flesh toward points vulnerability. Austen's literary world must have been open to viral reappropriation from the very beginning, if the virus has proven to be so successfu in making of her a disseminative tool-being. Marie Mulvey-Roberts's study pertaining to zombie adaptations of Jane Austen's work is especially instructive, in that it depicts the process of literary zombification exceedingly well. ${ }^{27]}$ As Mulvey-Roberts writes, the zombified mash-ups actualize $t \mid$ horrors lurking in the margins of Austen's novels, particularly slavery and war, at the same time as making ironic concessions to the decorum of Regency society, as in euphemisms for the zombies as 'unmentionables' or 'dreadfuls." "[28] Zombies function in the manner of viral black boxes, in $t$ sense that they are dreadfully unmentionable. In order to bypass security systems, viruses cannot communicate their dreadful interiors. Tool-beings general are black box-like entities; as Graham Harman states explicitly: 'the tool is a 'black box,' a simple integral unit that conceals an inferno of numerous interior powers and relations-forces utterly indifferent to any human 'use' of them."[29] Objects are already black boxes, cruel and duplicitous entities that are irreducible to their usages. This cruelty flows into various networks and relations through contagious overspills, renderin! virally overproductive hypertextual language catastrophic for meaning.

What "sense" could Sense and Sensibility, the Austen novel in question, have, if it is nothing more than the surface symptom of an abyssal, ungrounding infectiousness? As Mulvey-Roberts relates, even Jane Austen herself becomes, in certain works of contemporary fiction, "a vampire."[' Within the black box's inaccessible interior, we find a veritable inferno of intensities, running along parallel lines of programming text and undead informational flesh. The boundary line between "classical textuality" and pathogenic recombination is a precarious one that is questioned by the circumstance of viral reappropriation. What is Austen becoming when she is instrumentalized by malware? We could very well call this momentum $t$ "becoming-virus" of Jane Austen. Each becoming, when engendered by an exterior entity, is also an adaptation. The malware adapts Austen for its own malign purposes. Linda Hutcheon and Siobhan O'Flynn define adaptation as "a form of repetition without replication."[31] Mulvey-Roberts takes

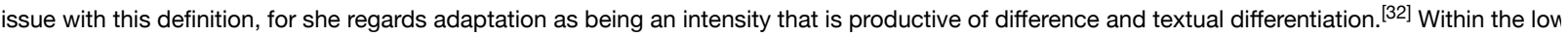
depths of the malware's programming language, we find intensities that testify to the irreducible presence of corporeal depressions and dreadful operativities, a multitude of mechanical desires and extensities. In this netherworld, we are powerless and incapable of even enumerating the variou levels signaled by the black box. Hypertextual overproductivity decomposes textualities exposed to its presence through "disrupting the linearity of the original." [33] Once decontextualized, every tool-being is rendered broken, albeit painfully present. This pain is an unavoidable aspect of transformation. The world is populated by countless multitudes of black boxes; indeed, for Harman, the world as such is composed of nothing apar from "interwoven contextures of meaning." [34] Sense is the mutual intermingling of various signals emitted by black boxes encountering one anothel upon the plane of immanence. This encounter is always subordinate to repetition, the extensity of desirous mutuality.

Individuality, be it that of a sentient being or a body of text, possesses, on the one hand, a "fixed number of definite properties" and, on the other, "c indefinite number of capacities to affect and be affected by other individuals." [35] True, the degree of openness to change on the part of such individuals may vary, but this dual aspect is one that cannot be restricted to a certain subset of privileged entities. All objects are multi-modal signal iterations. Systems of nonmeaning signify our own powerlessness, a vulnerability that is nevertheless not the sole preserve of any agent or network node. Viral dissemination is a spontaneous process, released by the throbbing, flashing inner world of a malicious program. Infection is a direct correlate of exhalation; illness is an ethereal atmosphere exhaled by already infected black boxes, transmitted through malign clouds. Each act dialogue between objects is nevertheless a personalized one; personalization need not entail the exclusion of repetition. There is a secret connectio between "echoing, allusion, and repetition, all of which are perfectly suited to hypertext linking."[36] Without this original affinity, viral repetition, as effectuated through hypertextual reappropriation, would not be successful in its endeavor. A hypertextual linkage can only be constructed once an underlying network, a preliminary infrastructure is in place. Only after emplacement upon this infrastrcture can adaptation take place, in the specifici "placial" sense of the word.

Interobjective dialogue operates on the level of textuality in the manner of a generative imperative. Within the lower depths of programming languag we discover a deeper layer, an "earth" replete with Dreadfuls not unlike those evoked by Mulvey-Roberts. It is at this point that we must delve deept among the various pieces of the networks, and, through an archaeological praxis, arrive at an understanding of viral operativity. The mutual resistanı we have identified, this zombie attack, overlaps well with the phenomenon of repetition. Klossowski writes of being as being composed of "syntheti interaction." "37] Wherever there is life, we find synthetic interaction, whether this be upon the surface of beings or within their subterranean, intensiv depths. The Dreadfuls, the informational undead, are trajectories that synthesize with their surroundings, while never pursuing anything beyond their own ends. What makes the virus and viral haunting particularly terrifying is their tautological nature. True, the programmers of viruses have certain well-defined material goals in mind. But the virus itself has only one goal, namely that of self-replication. Neither Chaos nor the Eternal Return," writ Klossowski, "pursue[s] any end other than themselves." [38] Chaos is more than some perverted, inverted re-presentation of the Law. Chaos is never mere lawlessness; it is the nonresistance engendered by mutational praxis. Once chaotic intensities engender their own repetitions, hard layers are degraded, decomposed through serpetine, subversive movements. There is something serpentlike in viral proliferation. The virus is not unlike a snal slithering underneath the foliage, ready to strike at its prey.

Viral atmosphericity, however, demands a place of susceptibility that precedes its advent. We may define the viral atmosphere as a vulnerable "oper a deterritorialized virtuality that is open to infection, like a piece of torn skin or a fractured stone. DeLanda defines the "virtual continuum" as "a heterogeneous space made out of a population of multiplicities, each of which is a topological space on its own. The virtual continuum would be, as were, a space of spaces, with each of its component spaces having the capacity of progressive differentiation." [39] Differentiation comes into play once repetition has found its place within a virtual "space of spaces." What else could the Internet be, if not precisely such a "space." Susceptibility 
and vulnerability are mere preludes to absolute degradation and incommunicable terror. If one were to define the world itself as a set of windows opening onto nothing else apart from one another's infinitely potentialized actualities, then one could very well see the entirety of Being as being composed of "a nested set of spaces... embedded into one another."[40] Rather than specifically discrete entities, what such a model would generat would be layers upon layers of powerlessness, fractured beyond repair, a cosmos composed of decomposed, broken tool beings. What the concep of the Vicious Circle allows us to visualize is the mediative function of empty adaptation. All texts are, in a sense, empty and void.

Pace Klossowski, "nothing here is the Circle once and for all." [41] Austen is already empty; repetitions are meaningless. The subject that repeats is, $f$ Klossowski, already one that has renounced its being. Repetition is a process of self-renunciation, an ecstatic moment of emancipation from subjectivity. It is in this sense that repetition is synthetic. ${ }^{[42]}$ Viral adaptation bridges various textual boundaries, connection excessively conserved textualities with the possibility of their subversion and undoing, as well as bringing classic texts to new audiences. It is of interest that infections woI through fascination and desire. Users are infected, protocols are penetrated, through the skillful use of camouflage. Classic textuality serves to intoxicate users and anti-virus software. Literary language, in the case of the Austen-virus, is an intoxicating glory, a soma deployed to subvert and destroy information-conservation systems. Order is replaced by chaos, the cosmos by what Gilles Deleuze has called the "chaosmos." Chaos and $t$ eternal return are not two distinct processes or entities, but form "a single and same affirmation." ${ }^{\text {"[3] }}$ Repetition is generative of chaotic difference. It no accident that Mulvey-Roberts connects the "zombie apocalypse" with the abyssal virtuality of chaos. ${ }^{[4]}$ Within every oscillation, we may identify "sensitive point...at which an external shock of the right intensity and duration can completely annihilate it." [45] Annihilation, however, need not be understood as a merely unproductive, negative term. The ending of one oscillation frees up the space of spaces, allowing for newer oscillations and multiplicity of intensities. Whereas the stimulus or shock serves as the death of one oscillation, it is also productive of other oscillations, movements and cycles. Zombie-being "figuratively tears apart and consumes the anterior text." ${ }^{[46]}$ But are not the zombies themselves also enslaved to a deept more malign force? After all, it is the hospital itself that keeps the ghosts in its thrall. The mental hospital seems to be the equivalent of the malware that enslaves Jane Austen. To be zombified is to be enslaved, trapped within a time-loop one cannot hope to escape from. The intoxicating literary glory of Austen's text enslaves our computer, but this textuality itself is exploited, flagellated and adapted by the virus lurking in the depths. Virally infected social subjects are locked into relations of fascination and emotional attachment; we are fascinated by Austen's zombified textuality, and hence infected by the virus, this somnambulist that works through a dual process of mesmerization and contamination. Infected agents are likened I Sampson to sleepwalkers "mesmerized and contaminated by the fascinations of their social environment." [47] In epidemological sociological discourse, the realm of the social becomes the equivalent of the viral and the bacteriological.

The topologies bred by chaotic zombification allows us to realize, with Deleuze, that every repetition is necessarily chaotic, and irreducible to humar intentionality. As Deleuze writes, "every typology is dramatic, every dynamism a catastrophe. There is necessarily something cruel in this birth of a world which is a chaosmos, in these worlds of movements without subjects, roles without actors."[48] Deleuze's ontology presents us with a world $n$ unlike a film without a script, a play without actors, a hospital with no patients, a time-loop with no exit. Repetition is the purity of empty significance an eminently material process that nevertheless leaves tragic marks and traces upon the faces of beings entangled in its spatiotemporal web. This system of entanglement operates through social adaptation; its productiveness is that of "a repetitious and contagiously capricious encounter with desire-events." "[99] Imitation and cannibalistic absorption, if it is to be successful, must be repeated. Imitational repetition is "triggered by the desireevent;"; $[50]$ in the case of the Austen-virus, we may add, a desire-event engendered by a productive and creative paratextual adaptation of Austen's textuality. The momentum of the "imitative encounter" identified by Sampson's reading of Tardean sociology actualizes the desire of Austen's reader transforming this original intention into an auto-consumptive dance of death. ${ }^{[51]}$ Rather than social relationality though, what we have in the cybernetically overcharged chaosmos is a post-vital biopower that reduces life to a trace, a remainder overdetermined by pathogenic determinants, a word: a chaotically disconnected space of spaces. Corporeal remnants are decomposed by undead mobile information technologies; pathogenassociated molecular agents burrow their way through security protocols, enveloped with protective paratextual skins. Tarde's contention that socia encoded desiring machines produce contagious cultural desires rests upon the idea of a separation between "biological" and "cultural" desire. ${ }^{[52]}$ In order to break down this distinction, we would argue for a different usage of "cultural." The readers of Austen are "cultures" in the bacteriological sense, bred by viruses for their own ends, serving as hosts for viral multiplicities. Infected internalities are literally awash with rapidly feeding microb It does not matter who Austen was; all that matters is that she operates as a desiring machine emanating imitative rays from her zombified body. Imitation, after all, "has a rare tendency to cascade or overspill." [53] Infection is a process of specification, a cascade that traverses unknown realms dodging immune reactions, intersecting with various sequences without delay. Signification is nothing if not an intensity. ${ }^{[5]}$

Information feeds into the overproduction of the remainder, the trace of death that haunts corridors, opening doors and closing exits, until we are all subsumed by that which lurks within the infrastructural basement. Within the Eternal Return, we do not have a "being there;" rather, we find "the fac of returning in what becomes." [55] Becoming-hauntological is to bridge ties with undead informational reality. Returning is becoming, an outlining of inconsistent realities complementing one another, acting as adjuncts to a vast inoperativity that envelops all those enveloped by its dark walls. Full chaos, chaos coming to fruition, is the coexistence of multiple alternatives. Chaos unfolds virtually; in a chaosmos, "each broken symmetry produc $\epsilon$ all the alternatives simultaneously, regardless of whether they are physically stable or not."[56] This "virtual unfolding" has profound temporal consequences, for the cascade generates an "absolute simultaneity" or "absolute coexistence." "[57] In other words, chaos is coexistence. We cannol hope for a harmonic model of social coexistence. The collecting of various antagonistic forces within one network can never be conflict-free; coexistence is a chaotic assemblage of disparate parts, operating without any discernible logic apart from that of viral proliferation. Underneath ord there resides a collection of chaotic, disordered intensities. Terrifyingly and unnervingly, we must reach the conclusion with Klossowski that science, social science in particular, "opens onto Chaos," but only in the final instance. ${ }^{[58]}$

Does hypertext, in the context of tautological, meaningless social space, still have a function? Jane Austen, as we have seen, is zombified and consumed by cybernetic overproduction. Her textuality, once separated from the body of her work, becomes a simulacrum of literary value, coverin! over the inner chaos of information. "The eternal return," Deleuze reminds us, "is not an external order imposed upon the chaos of the world; on the

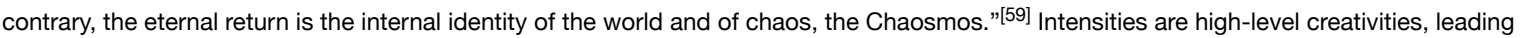


intentionality "back to the intensity of forces," generating "phantasms" and spectres. ${ }^{[60]}$ Repetition and, for that matter, repetitious textual appropriation, cannot be identified with any form of conservation. Deleuze, in his Difference and Repetition, is quite explicit on this point. Once local within the contexture of the eternal return, repetition "presupposes the dissolution of all prior identities." [61] Hypertext, the Austen-virus included, presents us with a liminal space, one that is "without linearity and sharp bounds between in and out," a spatio-temporality that is "between absence and presence."[62] Within coexistence, we must forgo the possibility of cohesion. Social cohesion and social coexistence, as we have seen, are mutually incompatible and mutually exclusionary terms. But instead of a clear dichotomy, hypertextual recycling of literary language presents us witl third possibility: that of chaosmotic social coexistence, a social format that comes into being after non-host resistance has failed and identity has been destroyed by the overwhelming onslaught of multiplicity. It is not that there are too few social alternatives, but rather, almost too many. Power today is so infamous that it has been dispersed into oblivion, which is not to say that it is nonexistent (quite the opposite!) Rather, power in the 21st century has become so dispersed as to become all-pervasive. Intensity has never been a fixed, solid entity; every apparent social solidification is periodically ungrounded by newer fluxes and the advent of alien alterities. No identity, no network is immune to the return of formlessness. The Austen-virus presents us with what Lev Manovich terms "higher-level automation," a kind of automation that allows for creative processes. ${ }^{\text {[63] New }}$ media are characterized by "deep remixability," the ability to recombine not only media content, but also "techniques, working methods, and ways $c$ representation and expression."[64] New media is a haunting that disturbs "the monological order of the symbolic field."[65]

In a sense, we may connect new media, in particular the genre of the mash-up, with zombification. This genre has left its mark on contemporary readings of Jane Austen's work, if for no other reason than for the fact that Austen has spawned a remarkable quantity of zombie-adaptations. What makes the zombie so captivating a subject for contemporary fiction authors? One may surmise that the secret lies within the actual operativity, or rather, inoperativity of contemporary viral society. Once reduced to the status of bacteriological culture, the victim of the viral attack becomes a carr of the disease. Zombies, these "brain-devouring monsters" consume the remains of infected Logos, definitively putting an end to logocentrism. [66] ॥ the case of the zombie-herd, we have a case of bad seed rising up against the ordered, modern world. The zombie apocalypse is a chaotic anarchy breeding that does not cease. Even after the brains of victims are consumed, chewed up and swallowed, the herd continues to proliferate and disseminate sick death across the social realm. There is virtually no limit to the numbers of undead, infected agents. What the zombie-apocalypse and, indeed, viral phenomena in general reveal, is the enormous amount of alternatives with which we are perpetually faced in social affairs. Pathogens spread across networks, defacing respectable landscapes and gardens, making a mess of social order and hierarchies. Bad seed refuse to submit to logos; even after the zombie herd has ripped apart Jane Austen's text, the zombies regurgitate her literary remnants, furthering the reac of the dreadful epidemic. Instead of a social ground, we find an ungrounded, insane social reality; the process of regurgitation and returning "is elaborated within a groundlessness in which original Nature resides in its chaos."[67] There is only one agonizing landscape within the eternal return; like a severed head rolling on the floor, the labyrinth of Chaosmos flashes before us, presenting a shocking visage. Within the eyes of the severed head, a head that could very well be that of Austen herself, we see mirrored a society in flames, capitalist democracy in its death throes. Once the eternal return is realized, in a moment of abyssal ecstasy, all that remains, the only landscape that does not collapse into irrelevance, is "depth, distance, caves, the lowers depths, the tortuous, and the unequal." [68] In the Chaosmos, there is a convergence within actuality. We ourselves are unequal to the task of confronting high-level creative automation; writing on the book trailer of, Pride Prejudice and Zombies, Camille Nelson highlig the importance of "zombie mayhem." [69] The connection between zombies and mayhem is a far from trivial one. The landscape of infectious mutuali is one in which consciousness and order have decayed into irrelevance. One could enumerate literally hundreds of examples of dilapidation and collapse as represented in various examples of the zombie genre.

Our intent in connecting the chaotic fictional landscape of zombie apocalypse and the very real virality of contemporary society is to shed light upor the emptiness of repetition, and its equation with chaos. As we have noted, the Deleuze of Difference and Repetition reaches the paradoxical conclusion that chaos is equivalent to the eternal return; repetition, far from being a moment of sterility or infertility, is actually fundamentally productive and generative. Chaos, as encapsulated by the temporal disordering and nonlinearity evident throughout Deleuze's philosophy, is nevertheless fundamentally inclusive. An important ramification of the multi-modality of chaos is that all series are included among its folds. Chaos enfolds, absorbing all entities trapped within its interiority: the only unity is one of unity in difference. As Deleuze points out, "the only unity, the only convergence of all the series, is an informal chaos in which they are all included."[70] Such a social form would constitute a situation that is characterized by absolute equality. Relating this to the issue of multiple textual interpretations and adaptations, including the viral adaptation of Janı Austen's Sense and Sensibility, we can say that no textuality may enjoy precedence over any other. Viral infection and proliferation, rather than closil down generativity, actually opens up new avenues of social change, reconstituting the literary tradition. The malware in question does not put an en to Austen, but rather, reinvents her, similarly to the zombie that bites and infects its victims. This form of annihilation, especially from the perspective the virus, is actually an affirmative act, however perverse a form it may happen to take. Each series and each textuality is "constituted by differences and communicates with the others through differences of differences," while order and hierarchical forms of representation are replaced by what Deleuze terms "crowned anarchies." [71] Instead of fidelity, zombiefied adaptation, even on a fictional level, contributes in a very real manner to the decomposition of discourses relating to purity and textual fidelity. ${ }^{[72]}$ Instead of retaining fidelity to any particular textual tradition, chaotic dissemination and zombiefied adaptation allow us to become infidels, faithless nomadic agents who reject sedentary, dense networks in favor of complete deterritorialization and detemporalization.

\section{Works Cited}

Allen, Graham (2000) Intertextuality. The New Critical Idiom (London and New York).

Cisco (2015) Midyear Security Report 2015 (San Jose: Cisco Systems Inc.).

Chun, Wendy Hui Kyong (2013) Programmed Visions. Software and Memory (Cambridge and London: The MIT Press). 
DeLanda, Manuel (2002) Intensive Science and Virtual Philosophy (London and New York: Continuum).

Deleuze, Gilles (1994 [1968]) Difference and Repetition, trans. Paul Patton (London: Athlone Press).

Galloway, Alexander (2011) "Black box, black bloc." Communization and its discontents: Contestation, critique, and contemporary struggles: $237-24$

Harman, Graham (2002) Tool-Being. Martin Heidegger and the Metaphysics of Objects (Chicago and La Salle: Open Court).

Hutcheon, Linda and O'Flynn, Siobhan (2013) A Theory of Adaptation (London: Routledge).

Klossowski, Pierre (1997 [1969]) Nietzsche and the Vicious Circle, trans. Daniel W. Smith (London: Athlone Press).

Landow, George P. (1992) Hypertext. The Convergence of Contemporary Critical Theory and Technology (Baltimore and London: The Johns Hopkins University Press).

Manovich, Lev (2013) Software Takes Command (London and New York: Bloomsbury Academic).

Mulvey-Roberts, Marie (2014) "Mashing up Jane Austen: Pride and Prejudice and Zombies and the Limits of Adaptation." The Irish Journal of Gothic and Horror Studies 13: 17-37.

Nelson, Camilla (2013) “Jane Austen... Now with Ultraviolent Zombie Mayhem.”Adaptation Vol. 6, No. 3, $338-354$.

Pride and Prejudice and Zombies. Dir. Burr Steers. (2016) West Wycombe, England, UK: Cross Creek Pictures, MadRiver Pictures, QC Entertainmen Allison Shearmur Productions, Handsomecharlie Films, Head Gear Films, PPZ Holdings.

Sampson, Tony D. (2012) Viral Theory. Contagion Theory in the Age of Networks (Minneapolis and London: University of Minnesota Press).

\section{Notes}

1. Cisco (2015) Midyear Security Report 2015 (San Jose: Cisco Systems Inc.), 13.

2. Ibid.

3. Landow, George P. (1992) Hypertext. The Convergence of Contemporary Critical Theory and Technology (Baltimore and London: The Johns Hopkins University Press), 66.

4. Ibid., 68.

5. Sampson, Tony D. (2012) Viral Theory. Contagion Theory in the Age of Networks (Minneapolis and London: University of Minnesota Press), 59

6. Ibid.

7. Allen, Graham (2000) Intertextuality. The New Critical Idiom (London and New York), 104.

8. DeLanda, Manuel (2002) Intensive Science and Virtual Philosophy (London and New York: Continuum), 60.

9. Sampson 2012: 59.

10. Cisco 2015: 13.

11. Sampson 2012: 59.

12. Ibid.

13. Ibid.

14. Sampson 2012: 60.

15. Klossowski, Pierre (1997 [1969]) Nietzsche and the Vicious Circle, trans. Daniel W. Smith (London: Athlone Press).

16. Chun, Wendy Hui Kyong (2013) Programmed Visions. Software and Memory (Cambridge and London: The MIT Press), 135.

17. Ibid.

18. Chun 2013: 133.

19. Allen 2000: 105.

20. DeLanda 2002: 60.

21. Landow 1992: 69.

22. DeLanda 2002: 61.

23. Ibid.

24. Chun 2013: 88.

25. Galloway, Alexander (2011) "Black box, black bloc." Communization and its discontents: Contestation, critique, and contemporary struggles: 237-249, 241.

26. Galloway 2011: 243.

27. Ibid.

28. Mulvey-Roberts, Marie (2014) "Mashing up Jane Austen: Pride and Prejudice and Zombies and the Limits of Adaptation." The Irish Journal of Gothic and Horror Studies 13: 17-37.

29. Ibid., 17-8.

30. Harman 2002: 243.

31. Mulvey-Roberts 2014: 18.

32. Hutcheon, Linda and O'Flynn, Siobhan (2013), A Theory of Adaptation (London: Routledge), p. xviii.

33. Mulvey-Roberts 2014: 21. 
34. Ibid.

35. Harman 2002: 260.

36. DeLanda 2002: 62.

37. Landow 1992: 142.

38. Klossowski 1997 [1969]: 35.

39. Ibid., 43.

40. DeLanda 2002: 69.

41. Ibid.

42. Klossowski 1997 [1969]: 58.

43. Ibid.

44. Deleuze, Gilles (1994 [1968]) Difference and Repetition, trans. Paul Patton (London: Athlone Press), 57.

45. Mulvey-Roberts 2014: 29.

46. DeLanda 2002: 85.

47. Mulvey-Roberts 2014: 33.

48. Sampson 2012: 13.

49. Deleuze 1994 [1968]: 219.

50. Sampson 2012: 23.

51. Ibid., 24.

52. Ibid., 25.

53. Ibid., 24-25.

54. Ibid., 25. (see diagram)

55. Klossowski 1997 [1969]: 65.

56. Ibid.

57. DeLanda 2002: 105-106.

58. Ibid., 106.

59. Klossowski 1997 [1969]: 135.

60. Deleuze 1994 [1968]: 299.

61. Klossowski 1997 [1969]: 140.

62. Deleuze 1994 [1968]: 202.

63. Landow 1992: 60.

64. Manovich, Lev (2013) Software Takes Command (London and New York: Bloomsbury Academic), 128.

65. Ibid., 46.

66. Allen 2000: 49.

67. Nelson, Camilla (2013) "Jane Austen... Now with Ultraviolent Zombie Mayhem." Adaptation Vol. 6, No. 3, 338.

68. Deleuze 1994 [1968]: 242.

69. Ibid.

70. Nelson 2013: 340; see also: https://www.youtube.com/watch?v=FzowFJTApfY.

71. Deleuze 1994 [1968]: 278.

72. Ibid.

73. Nelson: 342 .

\section{Cite this Essay}

https://doi.org/10.20415/rhiz/033.e02

RHIZOMES ISSN 1555-9998 $\star 230$ East Hall Bowling Green State University Bowling Green, OH 43403

Editors: Ellen Berry and Carol Siegel. Reviews editor: Craig J. Saper. Technical editor: Helen J Burgess 